\title{
Determination of Properties of Cookies Prepared with the Use of Peanut Milk Residue
}

\author{
Trushal L. Dharsenda* and Mukesh N. Dabhi
}

Department of Processing and Food Engineering, College of Agricultural Engineering and Technology, Junagadh Agricultural University, Junagadh, Gujarat (India)

*Corresponding author

\begin{abstract}
A B S T R A C T
Keywords

Cookies, Peanut, Peanut milk residue, Spread factor, Hardness

Article Info

Accepted:

04 October 2020

Available Online:

10 November 2020

The properties of cookies prepared with the use of peanut milk residue flour (PMR) were studied.In this study the mixing ratios of refined wheat flour (RWF) and peanut milk residue flour (PMR) were T-I (RWF:PMR=90:10), T-II (RWF:PMR=80:20), T-III (RWF:PMR=70:30), T-IV (RWF:PMR=60:40), T-V (RWF:PMR=50:50) respectively and for control $(\mathrm{RWF}=100)$. The physical properties i.e. length, width and thickness of developed cookies were increase with increases PMR with RWF and spread factor of developed cookies were decrease with increases PMR with RWF in this study. The hardness of developed cookies was significant decrease upon substitution of PMR with RWF. It was observed that the WAI and WSI were increases as the percentage of PMR in RWF increases. Cookies are ideal for nutrient availability, palatability, compactness and convenience. The main objective of this study was to investigate the effect of PMR on the several measurable characteristics of cookies.
\end{abstract}

\section{Introduction}

Protein deficiency is a major dietary problem facing the world today, particularly the underdeveloped and developing countries. Protein malnutrition is a serious problem in India due to cereal based dietary pattern. Therefore, various preparations based on cereal-pulse combination are of paramount importance to improve the protein quality of Indian diet. Protein rich cookies can be prepared from composite flours such as wheat flour fortified with soy, cottonseed, peanut or corn germ flours.
Peanut are probably the most important oilbearing seed in the world, and rapidly becoming a valuable source of plant protein.

Peanut seeds are a good source of protein, lipid and fatty acids for human nutrition (Taiand Young, 1975; Gaydou et al., 1983). Peanut proteins are relatively rich in amino acids needed for growth of school age children, except for lysine.

A large portion of vitamin B complex is destroyed during the roasting and blanching steps associated with peanut butter processing (Yeh et al., 2002). 
The peanut seeds yield non-drying, edible oil, used in cooking, margarines, salads, canning, and deep-frying; the oil content of the groundnut kernels is soluble vitamins (A, D, $\mathrm{E}$ and $\mathrm{K}$ ) and essential fatty acids.

In the peanut when oil can be removed the peanut protein could be concentrated on residual cakes and flours (Rhee et al., 1972 and 1973; Quinn and Beuchat, 1975;Kim et al., 1992 and Yu et al., 2007). The amino acid profile of peanut residual flours showed that it could bean ingredient for protein fortification (Yu et al., 2007). Peanut protein concentrates were obtained using raw and roasted, fermented and unfermented peanut flours ( $\mathrm{Yu}$ et al., 2007). These authors obtained peanut protein concentrates with 85 per cent protein versus 50 per cent protein in the defatted peanut flour.

Partially defatted peanut flour is an inexpensive and underutilized by-product from the peanut oil industry which is rich in protein and offers the same health and dietary benefits of peanuts but with less fat. The concentration of proteins from this material could increase its value and it could become a source of new protein with applications in different industries and processes, the objective of this study was to evaluate the use of the industrial by products peanut milk residue as substitute in the preparation of cookies and to investigate the effect of peanut milk residue (PMR flour) on the several measurable characteristics of protein rich cookies. Cookies are ideal for nutrient availability, palatability, compactness and convenience.

\section{Materials and Methods}

Refined wheat flour (maida), vanaspati ghee and sugar were purchased from the local market. PMR flour was purchased from the Nutrinity Foundation, GIDC, Junagadh.

\section{Preparation of cookies}

Preparation of cookies is made by traditional method.

\section{Physical properties}

The physical properties i.e. length, width, thickness and spread factor of cookies were studied and determined. The length, width and thickness were measured by Digital Vernier Calipers. The width and thickness was used for the measurement of the spread factor of developed cookies (Singh et al., 2008).

\section{Texture Profile Analysis (TPA)}

Texture measurements were carried out using the Texture Analyser (Stable Micro Systems, TA.XTplus). A flat rod probe $(25 \mathrm{~mm}$ in diameter) was attached to a $5 \mathrm{Kg}$ compression load. Texture profile analysis resulted in the calculation of instrumental hardness (as cutting by compression force) were measured.

\section{Functional properties}

The functional properties i.e. Water Absorption Index (WAI) and Water Solubility Index (WSI) of cookies were studied and determined as per method followed by Anderson et al., (1969).

\section{Statistical analysis}

The observed data were subjected to analysis of variance (ANOVA) using Completely Randomized Design (CRD) at 5\% level of significance $(\mathrm{p}<0.05)$.

\section{Results and Discussion}

\section{Physical properties}

The properties i.e. length, width, thickness and spread factor of developed cookies were determined as given in table 1 . 
Substitution of RWF with PMR caused a marked stiffening of dough. The size of the protein molecule apparently affected the dough texture and hence the cookies spread factor also. PMR substitution increased the thickness of cookies. These changes were significant at the $50 \%$ substitution level. Similar pattern was also found in the cookies substituted with $25 \%$ level in wheat flour (Beuchat, 1977). The use of cotton seed flour in a similar cookie formulation has also been noted to decrease the mean width and height (Fogg and Tinklin, 1972). Laboratory prepared wheat gluten and soy flour derivatives have also been reported to reduce cookies spread rapidly with increasing concentration and degree of functionality
(Kissell and Yamazaki, 1975).Pasha et al., (2011) found results that width was significantly affected by the addition of mungbean flour. Width of different treatments among which, the highest width was observed in $\mathrm{T} 5-25 \% \mathrm{MBF}(26.55)$ and the lowest $\mathrm{T} 1$ $5 \% \mathrm{MBF}(24.70)$. It was clear from the results that thickness was significantly affected by the addition of mungbeanflour. The highest thickness was observed inT4-20\% MBF (6.00) while thickness of cookies of treatment T1was the lowest (5.65). In this experiment the length, width and thickness was significantly increased with increase proportion of PMR but the overall length and width were lower than control sample.

Table.1 Physical characteristics of cookies prepared with different ratio of RWF and PMR

\begin{tabular}{|c|c|c|c|c|}
\hline Sample code & Length $(\mathbf{m m})$ & Width $(\mathbf{m m})$ & Thickness $(\mathbf{m m})$ & Spread factor \\
\hline Control & 39.77 & 38.26 & 21.44 & 1.785 \\
\hline T-I & 38.31 & 37.02 & $23.43^{\mathrm{a}}$ & 1.581 \\
\hline T-II & $38.45^{\mathrm{a}}$ & 37.12 & $23.48^{\mathrm{ab}}$ & 1.581 \\
\hline T-III & $38.48^{\mathrm{ab}}$ & 37.16 & $23.52^{\mathrm{abc}}$ & 1.580 \\
\hline T-IV & $38.53^{\mathrm{ab}}$ & 37.20 & $23.54^{\mathrm{bc}}$ & 1.580 \\
\hline T-V & $38.59^{\mathrm{b}}$ & 37.22 & $23.59^{\mathrm{c}}$ & 1.578 \\
\hline S Em \pm & 0.04 & 0.05 & 0.03 & 0.00 \\
\hline CD at 5\% & 0.12 & $\mathrm{NS}$ & 0.10 & $\mathrm{NS}$ \\
\hline CV\% & 0.20 & 0.27 & 0.28 & 0.35 \\
\hline
\end{tabular}

In the treatment $\mathrm{a}, \mathrm{ab} . .$. i.e. same letter shows that treatment was at par, NS- Non significant

Table.2 Hardness of cookies prepared with the use of PMR and RWF

\begin{tabular}{|c|c|}
\hline Sample code & Force $(\mathbf{k g})$ \\
\hline Control & 4.37 \\
\hline T-1 & 4.30 \\
\hline T-2 & 3.72 \\
\hline T-3 & 3.57 \\
\hline T-4 & 2.89 \\
\hline T-5 & 1.29 \\
\hline S Em \pm & 0.17 \\
\hline CD at 5\% & 0.55 \\
\hline CV\% & 9.61 \\
\hline
\end{tabular}

NS- Non significant 
Table.3 Water absorption index of cookies prepared with different ratio of RWF and PMR

\begin{tabular}{|c|c|}
\hline Sample code & WAI (\%) \\
\hline Control & 145.03 \\
\hline T-1 & 130.66 \\
\hline T-2 & 130.75 \\
\hline T-3 & 131.00 \\
\hline T-4 & 131.39 \\
\hline T-5 & 131.51 \\
\hline S Em \pm & 0.28 \\
\hline CD at 5\% & NS \\
\hline CV\% & 0.37 \\
\hline
\end{tabular}

NS- Non significant

Table.4 Water solubility index of cookies prepared with different ratio of RWF and PMR

\begin{tabular}{|c|c|}
\hline Sample code & WSI (\%) \\
\hline Control & 45.03 \\
\hline T-1 & 30.66 \\
\hline T-2 & 30.75 \\
\hline T-3 & 31.00 \\
\hline T-4 & 31.39 \\
\hline T-5 & 31.51 \\
\hline S Em \pm & 0.28 \\
\hline CD at 5\% & NS \\
\hline CV \% & 1.55 \\
\hline
\end{tabular}

NS- Non significant

The results pertaining to spread factor of cookies revealed a reduction in spread factor among treatments as the level of sweet potato flour was increased. The results elucidated that treatments had significant effect on spread factor of cookies due to replacement of different levels of sweet potato flour with plain wheat flour (Saeed et al., 2012). In this experiment the spread factor of cookies significantly decreases with increase the proportion of PMR and this may be due to increase in moisture content.

\section{Textural Analysis}

The values of hardness (as cutting by compression force) of cookies were tabulated in Table 2.
The values of hardness revealed the significant decrease upon substitution of PMR with RWF. Hardness of the experimental cookies gradually decreases with the progress of treatment. These results were different than Kohajdova et al., (2013) who observed that addition of Peanut flour concluded in increased hardness of cracker biscuits as well as the results observed in the study by Timbadiya (2013) in which hardness of cookies increased with increasing proportion of peanut butter.

\section{Functional properties}

The functional properties i.e. Water Absorption Index (WAI) and Water Solubility Index (WSI) of cookies were studied and determined as below, 


\section{Water absorption index (WAI)}

Result shows that the maximum water absorption index was $131.51 \%$, found in treatment $\mathrm{T}-5$, while minimum $130.66 \%$ in treatment T-1 (Table 3). From the result it was observed that the WAI increases as the percentage of PMR in RWF increases. Similar results were found by Abdel et al., (2011) for Bambara groundnut (Vigna subterranean). Mishra et al., (2012) were found that the $20 \%$ Soyabeanflour increase in water absorption capacity (WAC), probably due to the higher protein content of Soyabean.

\section{Water solubility index (WSI)}

Mixing with more PMR contain more starch particles than other mixing which contain more protein and fat particles, whose solubility is poor as compared to starch particles. The result was reflecting that the WSI increases as the percentage of PMR in RWF increases (Table 4).

In conclusion the result reflected in this experiment that there is a scope for use of PMR for the preparation of protein rich cookies and other bakery products. The substitution of PMR was up to $50 \%$ without significantly changes in most of the characteristics of cookies. Instrumental texture profile was an effective technique to select best in an acceptable range of cookies. Future studies are needed to develop different bakery product from PMR.

\section{References}

Abdel, R. S.; Eltayeb, M.; Ali O.; Azza A.; Abou-Arab and Ferial M. Abu-Salem (2011). Chemical composition and functional properties of flour and protein isolate extracted from Bambara groundnut (Vigna subterranean). African Journal of Food Science. Vol.
5(2), pp. 82-90.

Anderson, R. A.; Conway, H. F.; Pfeifer, V. F. and Griffin, E. L. (1969). Gelatinization of corn grits by roll and extrusion cooking. Cereal Science Today, Vol. (14), pp.4-6.

Beuchat, L. R. (1977). Modification of cookie-baking properties of peanut flour by enzymatic and chemical hydrolysis. Cereal Chem. Vol. 54(3), pp. 405-414.

Fogg, N. E. and Tinklin, G. L. (1972). Influence of glandless cottonseed flour on quality acceptability, and amino acid content of sugar cookies. Cereal Sci. Today. 17:70.

Gaydou, E. M.; Bianchini, J. P. and Ratovogery, J. (1983). Triterpene alcohols, methyl sterols, sterols andfatty acids five Malagasy legume seed oils. Journalof Agriculture and Food Chemistry, 31: 833-836.

Kim, N., Kim, Y.J. and Nam, Y.J. (1992). Characteristics and functional properties of protein isolates from various peanut (Arachis hypogaea L.) cultivars. J. Food Sci., 57: 406-410.

Kissel, L. T. and Yamazaki, W. T. (1975). Protein enrichment of cookie flours with wheat gluten and soyflourderivaties. Cereal Chem. 52:638.

Kohajdova, Z.; Karovicova, J. and Magala. M. (2013). Rheological and qualitative characteristics of pea flour incorporated cracker biscuits. Croat. J. Food Sci. Technol. Vol. 5 (1), pp. 11-17.

Mishra, V.; Puranik, V.; Akhtar, N. and Rai, G. K. (2012). Development and Compositional Analysis of Protien Rich Soyabean-maize Flour Blended Cookies. J Food Process Techno.3:182. doi:10.4172/2157-7110.1000182.

Volume 3, Issue 9.

Pasha, I.; Rashid, S.; Muhammad, A.; Sultan, M. T.; Qayyum, M. N. and Saeed, F. (2011). Quality Evaluation of WheatMungbean Flour Blends and Their 
Utilization in Baked Products. Pakistan Journal of Nutrition vol. 10 (4), pp. 388392.

Quinn, M.R. and Beuchat, L.R. (1975). Functional property changes resulting from fungal fermentation of peanut flour. J. Food Sci., 40: 475-479.

Rhee, K.C., Cater, C.M. and Mattil, K.F. (1972). Simultaneous recovery of protein and oil from raw peanuts in an aquous system. J. Food Sci., 37: 90-93.

Rhee, K.C., Cater, C.M. and Mattil, K.F. (1973). Effects of processing $\mathrm{pH}$ on the properties of peanut protein isolates and oil. Cereal Chem., 50 : 395-404.

Saeed, S.; Ahmad, M. M.; Kausar, H.; Parveen, S.; Masih, S. and Salam, A. (2012). Effect of sweet potato flour on quality of cookies. J. Agric. Res., 50(4), pp. 526-538.
Tai, Y. P. and Young, C.T. (1975). Genetic studies ofpeanut proteins and oils. Journal of American OilChemistry Society, 52: 377-385.

Timbadiya, P. (2013). Application of Peanut Butter to Improve the Nutritional Quality of Cookies. M.Sc. Thesis (Unpublished). College of Agricultural, JAU, Junagadh.

Yeh, J. Y.; Resurreccion, A. V. A.; Phillips, R. D. andHung, Y. C. (2002). Overall acceptability and sensory profiles of peanut spreads fortified with protein, vitamins and minerals. Journal of Food Sci., 67(5): 1979-1985.

Yu, J., Aahmedna M. and Goktepe I. (2007). Peanut protein concentrates: Production and functional properties as affected by processing. Food Chem., 103: 121-129.

\section{How to cite this article:}

Trushal L. Dharsenda and Mukesh N. Dabhi. 2020. Determination of Properties of Cookies Prepared with the Use of Peanut Milk Residue. Int.J.Curr.Microbiol.App.Sci. 9(11): 387-392. doi: https://doi.org/10.20546/ijcmas.2020.911.047 